\title{
Psikolojik danışma ve rehberlik öğrencilerinin özel eğitim dersi sürecindeki kazanımlarının belirlenmesi $\left.{ }^{\star *}\right]$
}

\author{
İlker KÖSTERELİOĞLU ${ }^{[* *]}$ \\ Kemal BAYTEMIR ${ }^{[* *]}$
}

\begin{abstract}
Öz
$\mathrm{Bu}$ araştırmada Amasya Üniversitesỉnde öğrenim gören psikolojik danışman ve rehberlik öğrencilerinin, öğretim programlarında yer alan özel eğitim ders programını tamamladıktan sonra öğrencilerde hangi kazanımların gerçekleştiğinin belirlenmesi amaçlanmıştır. Araştırma 20132014 eğitim öğretim yılının güz yarıyılında 51 öğrenci ile yürütülmüştür. Veriler ders sonunda elde edilen dokümanların betimsel analizi yapılarak analiz edilmiştir. Veriler incelendiğinde öğrenciler 17 başlık altında özel eğitim alanında karşılaşabilecekleri durumları ifade etmişlerdir. Veriler her başlık altında, belirtilen durumlarda öğrencilerin neleri yapacaklarını belirten frekans sayısı verilerek sunulmuştur. Araştırma bulgularına bütüncül olarak özetlendiğinde, öğrencilerin karşılaşabilecekleri engel ve güçlük alanlarının tümüne vurgu yaptıkları ve her başlık altında yapacakları davranış ve gösterecekleri tutum ifadelerinin de incelendiğinde kabul edilebilir düzeyde olduğu sonucuna varılmıștır. Araştırmada dikkat çeken diğer bir bulgu, farklı yetersizlik alanlarına geçildiğinde o alanın niteliğiyle uyumlu olarak öğrencilerin kazanımlarının da farklılık gösterdiği yönünde olmasıdır.
\end{abstract}

Anahtar kelimeler: Özel eğitim, özel eğitim dersi, psikolojik danışma ve rehberlik, kazanım

\section{Identification of psychological counseling and guidance students' gains during special education classes}

\begin{abstract}
Current study aimed to identify the acquisitions of psychological counseling and guidance students at the Amasya University following their completion of special education courses. The study was conducted with 51 students in the 2013-2014 academic year. Data were analyzed with the help of

[*] Bu araştırma $9^{\text {th }}$ International Balkan Education and Science Congress'inde sözlü bildiri olarak sunulmuştur.

[*] Yrd. Doç. Dr., Amasya Üniversitesi Eğitim Fakültesi, Eğitim Bilimleri Bölümü, ikostereli@hotmail.com

${ }^{[* * *]}$ Yrd. Doç. Dr., Amasya Üniversitesi Eğitim Fakültesi, Eğitim Bilimleri Bölümü, kemalbaytemir@hotmail.com
\end{abstract}


descriptive analysis of the documents collected at the end of the course. During the analyze phase the situations that can be encountered in special education was grouped under 17 themes. Data were presented with frequency for each theme that showed what could be done in each situation. Holistic interpretation of research findings points to the fact that students emphasized the entirety of barriers and problem situations and they presented acceptable levels in their behavioral and attitudinal responses for each theme. Another interesting finding of the study is related to the fact that student acquisitions differed based on the characteristics of the field in question.

Keywords: Special education, special education course, psychological counseling and guidance, acquisition

\section{Giriş}

Çeşitli nedenlerin etkisiyle bireysel özellikleri ve eğitim yeterlilikleri açısından yaşıtlarından beklenilen düzeyden anlamlı farklılık gösteren bireyler özel eğitime ihtiyaç duymaktadırlar. Özel eğitime ihtiyaç duyan bireylerin eğitim ihtiyaçları, bu alana uygun olarak yetiştirilen personel ve geliştirilen bireysel eğitim programlarında (BEP) öğrencilere uygun seçilen yöntemler ve uygun ortamlarda sürdürülen eğitimle karşılanmaya çalışılmaktadır.

Özel gereksinimli bireyler de normal bireyler gibi gereksinimlerini en iyi şekilde karşılayacak eğitim hizmetlerinden yararlanma hakkına sahiptirler. Özel gereksinimli bireylerin eğitim gereksinimlerinin karşılandığı eğitim ortamları farklılık göstermektedir. Bu ortamlar; özel okullar, normal okullardaki özel sınıflar ve normal sınıflardır. Bunlar arasında, normal sınıflarda sunulan eğitim, yani "kaynaştırma eğitimi” son yıllarda giderek yaygınlaşmaktadır (Batu, Kırcaali-İftar ve Uzuner, 2004). Özel gereksinimli bireylere sağlanan eğitim ortamları içerisinde "en az kısıtlayıcı eğitim ortamının en üst seviyesini oluşturan kaynaştırma uygulamasında, herhangi bir özür grubundaki öğrenciye gerekli destek hizmetler sağlanarak normal sınıf içinde eğitim verilmesi amaçlanmaktadır (Gözün ve Yıkmış, 2004).

Özel eğitim hizmetleri yönetmeliğinde (MEB, 2012) kaynaştırma yoluyla eğitim; özel eğitime ihtiyacı olan bireylerin eğitimlerini, destek eğitim hizmetleri de sağlanarak yetersizliği olmayan akranları ile birlikte resmî ve özel; okul öncesi, ilköğretim, orta öğretim ve yaygın eğitim kurumlarında sürdürmeleri esasına dayanan özel eğitim uygulamalarını kapsamaktadır. Kaynaştırma uygulamalarının başarısı, özel eğitime gereksinimli bireylerin gerekli özel eğitim ve normal eğitim hizmetlerini yeterli biçimde alabilmelerine bağlıdır (Saraç ve Çolak, 2012). Aynı zamanda kaynaştırma uygulamasının başarısı bir ekip çalışmasını gerektirir. Kaynaştırma yoluyla eğitim uygulaması yapılan okul ve kurumlarda, BEP geliştirme birimi oluşturulmaktadır. BEP birimi, özel eğitime ihtiyacı olan öğrencilerin devam ettikleri programları temel alarak eğitim performansı ve ihtiyaçları doğrultusunda BEP hazırlamaktan sorumludur. BEP, özel gereksinimli öğrenciye kazandırılacak davranışların neler olduğunu, bunların nasıl, nerede ve ne kadar süreyle ve ne zaman kazandırılacağını belirlemeye çalışan bir plandır (Kargın, 2010). BEP 
geliştirme biriminde özel gereksinimli çocuğun kendisi, ailesi, rehber öğretmen, uzmanlar ve yöneticiler bulunmaktadır. BEP'in başarıya ulaşmasında ilgili kişilerin işbirliği yapmaları ve bir amaç doğrultusunda birlikte hareket etmeleri önem kazanmaktadır.

Özel gereksinimi olan bireylerin toplum içinde bağımsız bir şekilde yer alabilmeleri için çevrelerindeki pek çok kişi, kurum ve kuruluşa görev düşmektedir. Bu konuda, özel gereksinimi olan bireylerin ailesinden sonra en önemli rol okul personeline düşmektedir. Özel gereksinimi olan çocuklarla farklı disiplinlerde pek çok personel hizmet vermektedir (Batu, 2013). Özel eğitim alanında hizmet veren personellerden birisi de psikolojik danışma ve rehber öğretmenlerdir.

Her birey kendine özgü bir varlık olup çeşitli niteliklere farklı düzeylerde sahip olabilir. Bu durum yetersizlik yaşayan bireyler için de böyledir. Engelli birey bazı yeteneklerden yoksunluk yaşadığından topluma uyumu güçleşebilmektedir. Özel eğitim alanında bireyin çevreye uyumuna ve meslek edinme sürecine yardımcı olmak psikolojik danışmanlık ve rehberlik hizmetleri içerisinde yer alır. Engelli bireyin de diğer bireyler gibi güçlü yanlarının geliştirilmesi bireye saygı açısından gereklidir (Kuzgun, 2000).

Özel eğitime özgü psikolojik danışmanlık ve rehberlik söz konusu değildir. Psikolojik danışma ve rehberlik hizmetlerindeki amaç, ilke, hizmet birimleri, teknik ve araçlar vb. tüm bireyler için geçerlidir (Bakırcıoğlu, 2005). Psikolojik danı̧̧ma ve rehberlik hizmetlerinin "rehberlik hizmetleri tüm öğrencilere yöneliktir", "rehberlik hizmetlerinde bireysel farklılıklara sayg1 esastır" ve "her birey saygı duyulmaya değerdir” (Kuzgun, 2000; Bakırcıŏlu, 2005; Yeşilyaprak, 2013) gibi bazı temel ilkelerinde de görüleceği üzere psikolojik danışmanlık ve rehberlik hizmetlerinden normal öğrencilerin yanısıra özeleğitime ihtiyaçduyanöğrencilerin deyararlanmasına olanakvermektedir.

Türkiye’de özel eğitim alanında en önemli problemlerden birisinin özel eğitime ihtiyacı olan birey sayısının bilinmemesidir. Bu düşünceyi belirten Şenel (1998) bu kapsamda bulunan bireyleri tarama ve tanımlama zorunlu olduğunu, bu nedenle ilgili disiplinlerin temsilcilerinden oluşan bir çalışma grubunun gerekli olduğunu ifade etmektedir. Özel eğitim hizmetleri yönetmeliğine (MEB, 2012) bakıldığında özel eğitime ihtiyacı olan öğrencilerin tespit edilmesine, tanılanmasına ve yerleştirmelerinin yapılmasına kadar pek çok kurulun oluşturulmuş olduğu görülmektedir. Psikolojik danışman ve rehber öğretmenlerin özel eğitim hizmetleri kurulunda, özel eğitim değerlendirme kurulunda ve BEP kurulunda yer aldığı görülmektedir. Bu bakımdan özel eğitime ihtiyacı olan öğrencilerin erken tespitinde, tanılama, yönlendirme ve yerleştirilmesi sürecinde psikolojik danışman ve rehber öğretmenler bu sürecin önemli bir parçası olmaktadırlar. Yine özel eğitim hizmetleri yönetmeliğinde (MEB, 2012) rehber öğretmenin kurumdaki rehberlik ve psikolojik danışma hizmetlerinin yanında özel eğitime ihtiyacı olan bireyin ailesi, öğretmenleriyle ve özel eğitime ihtiyacı olan öğrencinin gelişimi ve değerlendirilmesinde ilgili kurullarla işbirliği yapması gerektiği vurgulanmaktadır. Özel eğitime gereksinimi olan öğrencilerin eğitsel tanılamaları il ve bazı ilçelerde bulunan Rehberlik ve Araştırma Merkezleri (RAM) tarafından yapıldığı için rehber öğretmenler önemli görevler üstlenmektedirler. Rehber öğretmenler, ayrıca özel gereksinimi olan öğrencilerin sergiledikleri problem davranışlarda ve öğrenmeyle ilgili sorunlarında sınıf ve branş öğretmenlerinin ilk danıştıkları kişilerdirler. Rehber öğretmenlerin 
bu gibi sorunlara doğrudan ya da dolaylı olarak müdahale etmek gibi bir rol ve sorumlulukları vardır (Aksoy ve Diken, 2009).

Türkiye’de özel eğitim alanında uzman yetiştiren yeterli sayıda yüksek öğretim kurumu mevcut değildir. Dolayısıyla özel eğitim alandaki ihtiyaca henüz cevap verebilecek sayıda özel eğitim öğretmeni bulunmamaktadır. Özel eğitim öğretmenlerinin sayıca yetersizliği ve özel eğitim alanı dışındaki öğretmenlerin özel eğitime ilişkin yeterli eğitim alamaması sonucunda özel eğitime ihtiyacı olan öğrencilerle karşılaştıklarında hayal kırıklı̆̆ı yaşayabilmektedirler (Melekoğlu, Çakıroğlu ve Malmgren, 2009). Öğretmenlerin kaynaştırmaya ilişkin yeterli bilgi sahibi olmamaları ve bunun sonucunda sınıfındaki kaynaştırma uygulamalarında yetersiz kalmaları ve dolayısıyla sorunlar yaşadıkları (Gök ve Erbaş, 2011), öğretmenlerin özel eğitimde kaynaştırma hizmetlerine yönelik ders veya eğitim almalarının kaynaştırmaya yönelik olumlu tutum geliştirmekle ilişkili olduğu (Orel, Zerey ve Töret, 2004; Gözün ve Yıkmış, 2004) araştırmalarda vurgulanmaktadır.

Psikolojik danışman ve rehber öğretmenlerin yukarıda da vurgulandığı üzere özel eğitim alanında; öğrencilerin tanılanması, okul içerisinde bireysel eylem planlarının hazırlanması, yürütülmesi ve değerlendirilmesi, bireyin özel eğitim alanındaki ihtiyaçları doğrultusunda fikir sunması, ailelerle çocuğun gelişimi hakkında bilgilendirmek ve aileye yönelik rehberlik yapma ve okulda uygun öğrenme ortamlarının hazırlanması gibi alanlarda doğrudan ve dolaylı olarak faaliyet göstermektedirler. Bu nedenle özel eğitim dersinin psikolojik danışma ve rehberlik öğrenimi gören öğrencilerin öğretim programlarında yer alması ve etkili biçimde kazanımlarının sağlanması oldukça önemlidir. Rehber öğretmenlerin sahip oldukları bilgi, beceri, tutum ve deneyimlerinin yanı sıra özel eğitime gereksinim duyan çocukların yaşayabilecekleri sorun alanlarına ilişkin öz yeterlik algıları eğitim sürecine etki eden önemli bir değişken olmaktadır (Aksoy ve Diken, 2009).

\section{Araştırmanın amacı}

Bu araştırmada 2013-2014 eğitim öğretim yılında Amasya Üniversitesi’nde öğrenim gören psikolojik danışman ve rehberlik öğrencilerinin öğretim programlarında yer alan özel eğitim dersini tamamladıktan sonra bu dersin kendilerinde hangi kazanımlar sağladığının belirlenmesi amaçlanmıştır. Araştırmanın problem cümlesini "Psikolojik danışman ve rehberlik öğrencilerinin özel eğitim dersi programına ilişkin kazanımları nelerdir?” oluşturmaktadır.

\section{Araştırmanın önemi}

Ülkemizde Engelli ve Yaşlı Hizmetleri Genel Müdürlügü tarafından yetkili sağlık kuruluşları tarafından engelli sağlık kurulu raporu almış ve veri tabanına bilgi akışı sağlanabilen bazı kamu kurum ve kuruluşlarına herhangi bir sebepten dolayı başvurmuş engelli bireylerin verilerinin derlenmesi ile oluşan verilere göre engellilerin güncel sayısı 1.802.865 olduğu ifade edilmektedir. Bunun yanı sıra ülkemizde engelli vatandaşların oranının nüfusumuzun \%12.7'si olduğu belirtilmektedir. Toplumda engelli bireylerin varlığını kabul etmek bir zorunluluk olmakla birlikte yetişen bireylerin engellilerin varlığı ve özelikleri konusunda bilgilenmesi önemli bir konu alanıdır. 
Bu bağlamda özellikle toplumda önemli bir etki gücüne sahip mesleklerin başında öğretmenlik mesleği gelmektedir. Yetişen nesli belli bilgi, düşünce ve değerler doğrultusunda yetiştirmede etkin sorumluğu olan öğretmenlerin toplumda yer alan engel grupları konusunda bilgilenmesi önemli bir konudur. Öğretmen yetiştiren eğitim fakültelerinde belirtilen ihtiyaç özel eğitim dersi ile karşılanmaktadır. Öğretmenlerin okulunuzda öğrenme güçlüğü yaşayan bir öğrenci, davranışlarıyla okulda sorun yaratan bir öğrenci, öğrenme konusunda akranlarına göre daha üst düzey düşünme ve üretme konusunda etkin olan bir öğrenci ile karşılaşıldığında öncelikle öğretmenlerin rehber öğretmene başvurmak gibi bir yönelimleri vardır. Bu durum psikolojik danışman ve rehber öğretmenlerin özel eğitim konusunda öğretmenleri bilgilendirecek ve yönlendirebilecek niteliklere sahip olmalarını gerekli kılmaktadır. Bu araştırma psikolojik danışma ve rehber öğretmenlerin görüşlerine göre özel eğitim dersini tamamladıktan sonra elde ettikleri kazanımların belirlenmesi ve beklentilere uygun niteliklere sahip olup olmadıklarının tartışılmasına olanak vermesi beklenmektedir.

\section{Yöntem}

\section{Araştırma modeli}

Araştırma nitel bir araştırmadır. Nitel araştırmada araştırmacılar "ne kadar" ve "kaç tane" gibi rakamsal sonuçlara ulaşmakla birlikte, insanlar deneyimlerini nasıl yorumlamaktadırlar ve deneyimlerine nasıl bir anlam yüklemektedirler gibi neden ve etkiyi belirlemeye çalışırlar (Merriam, 2013). Araştırmada öğrencilerin özel eğitim dersini alan psikolojik danışma ve rehberlik öğrencilerinin bu ders programını tamamladıktan sonraki kazanımlarının ortaya konulması istenmiştir. Bu bağlamda öğrencilere dersin sonunda yapılan düzey belirleyici (summative) değerlendirmeye ek olarak öğrencilere sorulan açık uçlu bir soruya ilişkin görüşleri değerlendirilmiştir. Bu bağlamda yürütülen araştırma doküman analizine dayalı nitel bir araştırmadır (Yıldırım ve Şimşek, 2005).

\section{Araştırma grubu}

Araştırma grubunu 2013-2014 eğitim-öğretim yılı güz döneminde Amasya Üniversitesi Eğitim Fakültesi bünyesinde psikolojik danışma ve rehberlik alanında ikinci sınıfta öğrenimlerine devam eden öğrenciler ( $\mathrm{N}=51$ ) oluşturmaktadır.

\section{Tablo I}

Araştırmaya Katılan Öğrencilerin Demografik Özellikleri

\begin{tabular}{|c|c|c|c|}
\hline \multicolumn{2}{|c|}{} & f & $\%$ \\
\hline \multirow{3}{*}{ Cinsiyet } & Erkek & 18 & 35 \\
\cline { 2 - 4 } & Kadın & 33 & 65 \\
\cline { 2 - 4 } & Toplam & $\mathbf{5 1}$ & $\mathbf{1 0 0}$ \\
\hline
\end{tabular}


Tablo 1 incelendiğinde araştırma grubunda yer alan öğrencilerin \% 65’i kadın, \% 35,i erkek öğrencilerden oluşmaktadır.

\section{Uygulama süreci}

Öğretmen yetiştiren fakültelerin öğretim programlarında okutulan özel eğitim dersi, özel eğitime ihtiyaç duyan, engel gruplarının özelliklerinin tanıtılması ve bu bireylere farkındalık sağlanmasını amaçlayan bir derstir. Daha ayrıntılı olarak bakıldığında bu dersin programının tamamlanması ile öğretmen adaylarının; özel eğitimin tanımı, özel eğitimle ilgili temel ilkeler, engelliliği oluşturan nedenler, erken tanı ve tedavinin önemi, engele bakışla ilgili tarihsel yaklaşım, zihinsel engelli, işitme engelli, görme engelli, bedensel engelli, dil ve iletişim bozukluğu olan, süregelen hastalığı olan, özel öğrenme güçlüğü gösteren, dikkat eksikliği ve hiperaktivite, otizm belirtisi taşıyan, üstün yetenekli çocukların özellikleri ve eğitimleri, farklı gelişen çocukların oyun yoluyla eğitimi, özel eğitime muhtaç çocukların ailelerinde gözlenen tepkiler, ülkemizde özel eğitimin durumu, bu amaçla kurulmuş kurum ve kuruluşlar konusunda bilinçlenmelerinin sağlanması amaçlanmaktadır. Bu amaçla yürütülen özel eğitim dersinin dönem sonunda öğrencilere sunulan iki soruya verdikleri cevaplara dayanarak elde edilen kazanımlar belirlenmeye çalışılmıştır.

\section{Veri toplama yöntemi ve aracı}

Araştırmada veriler öğrencilere sunulan açık uçlu bir soruya verdikleri cevaplardan elde edilmiştir. Öğrencilere; "Özel eğitim mesleki yaşamınızda nerelerde karşınıza çıkacağını düşünüyorsunuz?” ve "Böylesi durumlarla karşılaştığınızda neler yapacağınızı belirtiniz?"

soruları yöneltilmiştir. Öğrenciler sorulara yazılı olarak yanıt vermiştir. Öğrencilerin sorulara verdiği yanıtlar sınırlılığında nitel veriler içeren doküman, analiz edilmiştir.

\section{Verilerin analizi}

Araştırmacılar belirtilen dokümanda öğrencilerin ifade ettikleri görüşleri cümle cümle okuyarak betimsel olarak analiz etmişlerdir. Bu aşamada öğrencilerin birbirine benzeyen görüşlerine frekans verilerek frekans tabloları oluşturularak veriler sunulmuştur.

\section{Bulgular}

$\mathrm{Bu}$ bölümde psikolojik danışma ve rehberlik öğrencilerinin özel eğitim ders sürecindeki kazanımlarına yönelik görüşleri aşağıda tablolar halinde sunulmuştur. 
Marmara Üniversitesi Atatürk Eğitim Fakültesi Eğitim Bilimleri Dergisi / Journal of Educational Sciences Yıl: Haziran 2016 • Cilt-Sayı 44・ISSN: |300-8889・ ss. 53-7|

\section{Tablo 2}

Öğrencilerin Özel Eğitim Ille Karşılaşacakları Durumlara Ilişkin Görüşleri

\begin{tabular}{|l|c|c|c|}
\hline \multicolumn{1}{|c|}{ ALAN } & GÖRÜş BELİRTEN & f & $\begin{array}{c}\text { MADDE } \\
\text { ÖGYISI }\end{array}$ \\
\hline Duygu ve davranış bozuklukları & 22 & 46 & 14 \\
\hline Üstün zekalı öğrenciler & 21 & 36 & 10 \\
\hline Fiziksel-ortopedik yetersizlik & 21 & 42 & 10 \\
\hline Kaynaştırma öğrencisi & 21 & 53 & 14 \\
\hline Zihinsel yetersizlik & 14 & 36 & 6 \\
\hline Öğrenme güçlüğü & 12 & 20 & 7 \\
\hline Bireysel eğitim planı hazırlamak & 12 & 12 & 1 \\
\hline Otizm & 10 & 17 & 7 \\
\hline Konuşma ve dil bozukluğu & 9 & 17 & 9 \\
\hline Hiperaktivite & 9 & 11 & 6 \\
\hline Konvülsiyon bozukluk (sara) & 9 & 19 & 5 \\
\hline Tarama faaliyeti & 7 & 7 & 1 \\
\hline Özel eğitime ihtiyaç duyan bireyin ailesi & 5 & 7 & 3 \\
\hline İşitme güçlüğü & 5 & 6 & 5 \\
\hline Görme güçlüğü & 3 & 5 & 2 \\
\hline Süreğen hastalıklar & 1 & 1 \\
\hline Özel eğitime ihtiyaç duyan bir çocuk annesi & & 1 \\
\hline
\end{tabular}

Araştırmaya katılan öğrenciler Tablo 2'de ifade edildiği üzere özel eğitim ile ilgili karşılaşacakları durumları ifade eden görüşleri 17 başlık altında toplanmaktadır. Tablo 2'de araştırmaya katılan $n=51$ öğrencinin görüşleri incelendiğinde öğrenciler; duygu ve davranış bozukluğu ( $n=22)$, üstün zekâlı öğrenciler $(n=21)$, fiziksel ve ortopedik yetersizlik $(n=21)$ ve kaynaştırma öğrencisi $(n=21)$ olarak en fazla karşılaşacakları durumları belirtmişlerdir. Tablo 2'de dikkat çeken iki ayrı bulgu yer almaktadır. Bunlardan birincisi bir engel alanı olmadığı halde öğrencilerin engelli bireylerin belirlenmesine ilişkin tarama faaliyetinde bulunacaklarını $(n=27)$ ve bireysel eylem planı hazırlamak $(n=12)$ durumunda kalacaklarını ifade etmeleridir. İkinci bulgu ise özel eğitime ihtiyaç duyabilecek bir çocuk annesi olarak bu gerçekliği yaşayabilirim düşüncesinde olabileceğini düşünen sadece bir öğrencinin olmasıdır. 
Tablo 3

Öğrencilerin Duygu ve Davranış Bozukluğuna Illişkin Görüşlerinin Frekans Değerleri (n=22)

\begin{tabular}{|l|c|}
\hline Duygu ve davranış bozuklukları & f \\
\hline Öğrencinin davranışını gözlemleyerek veri oluşturmak & 6 \\
\hline Aileyle görüsşerek gözlem sonuçlarını paylaşmak & 6 \\
\hline Aileye bozukluğun olası nedenleri hakkında görüşerek bilgilendirmek & 5 \\
\hline Öğrenciye ilgi ve sabır göstermek & 5 \\
\hline Öğrencinin duygu ve davranışlarını ifade edecek etkinlikler hazırlamak & 3 \\
\hline Öğretmene destek olmak & 5 \\
\hline Ailenin çocuğa ilgi göstermesini sağlamak & 3 \\
\hline Aile ve öğretmenle görüşrerek ilgi ve sabır gösterilmesini sağlamak & 3 \\
\hline $\begin{array}{l}\text { Arkadaşları tarafından etiketlenmesini ve ruhsal açıdan hırpalanmasını (zedelenmesini) engellemeye } \\
\text { çalışmak }\end{array}$ & 2 \\
\hline Çocuğa sorumluluk verecek etkinlikler düzenlemek & \\
\hline Aileye müşavirlik hizmetleri yürütmek & 4 \\
\hline İçe yönelimli durumlarda yazı yazdırarak kendini ifade etmesini sağlamak & 1 \\
\hline Cocukla beraber sınıf kurallarını belirlemek & 1 \\
\hline Öğrenciye bireysel danışma yapmak & 1 \\
\hline & 1 \\
\hline
\end{tabular}

Tablo 3 incelendiğinde $n=22$ öğrenci duygu ve davranış bozukluğuna ilişkin görüş belirtilmektedir. Öğrencilerin duygu ve davranış bozukluğu durumu ile karşılaştıklarında en fazla frekansı öğrencinin davranışını gözlemleyerek veri oluşturmak ve aileyle görüşerek gözlem sonuçlarını paylaşmak davranışlarını gösterme eğiliminde bulunacaklarını ifade etmektedirler. Yine aileyi bu durumun olası nedenleri hakkında bilinçlendirme ve öğrenciye ilgi ve sabır gösterilmesi gerektiği öğrenciler tarafından vurgulanmaktadır. Ayrıca öğrencilerin duygu ve davranış bozukluğu yaşayan öğrencilere sorumluluk vermek, duygularını ifade edecek etkinlikler düzenlemek ve öğrencilerin kendini ifade etmede desteklemek biçiminde davranışsal tepkileri olacağ 1 belirtilmektedir.

\section{Tablo 4}

Öğrencilerin Üstün Zekâlı Çocuklara Ilişkin Görüşlerinin Frekans Değerleri (n=2I)

\begin{tabular}{|c|c|}
\hline Üstün zekâlı çocuklar & f \\
\hline Öğrencileri yetenekleri doğrultusunda eğitim almak için RAM’a yönlendirmek & 8 \\
\hline Öğrenciyi bilim sanat merkezlerine yönlendirmek & 6 \\
\hline İlgi ve istidatlarına uygun ödev ve projelere yönlendirmek & 4 \\
\hline Tanilayıcı testler uygulamak & 4 \\
\hline Öğrencinin erken teşhis edilmesini sağlamak & 4 \\
\hline Öğrenciyi ders dıșı yetenekleri doğrultusunda aktivitelere yönlendirmek & 3 \\
\hline Çocuğun körelmemesi için üst sınıflardan ders aldırmak & 3 \\
\hline Üstün zekâlı öğrencilerin de özel eğitime ihtiyaç duyduğu bilincini olușturmak & 2 \\
\hline $\begin{array}{l}\text { Öğretmenleri öğrencilerin merak duygusu ve çalışma hızlarını olumsuz etkileyecek davranışlardan } \\
\text { uzak durmaları için yönlendirmek }\end{array}$ & 1 \\
\hline Okulda özel sınıf açılması için müdürle irtibata geçmek & 1 \\
\hline Toplam & 36 \\
\hline
\end{tabular}


Tablo 4’te n=21 öğrenci üstün zekalı olabilecek öğrencilerle karşılaşabileceklerini belirtmektedirler. Öğrenciler özellikle bu durumda olan bireyleri yetenekleri doğrultusunda eğitim almaları için RAM’a yönlendirilmesi gerektiği ve bilim sanat merkezlerine yönlendirilmesi gerektiğini düşünmektedirler. Öğrenciler üstün yetenekli öğrencilerle karşılaştıklarında öğrencileri ilgilerine göre yönlendirmek, tarama testleri yapmak, ders dışında yetenekleri doğrultusunda aktivitelere yönlendirmek ve erken tanının önemli olduğunu ifade etmektedirler. Tablo 4’te göze çarpan diğer kıymetli bir bulgu ise üstün yetenekli öğrencilerin de özel eğitime ihtiyacı olduğu konusunda bilinçli olduklarını ifade etmeleridir.

\section{Tablo 5}

Öğrencilerin Fiziksel ve Ortopedik Güclüğe llişkin Görüşlerinin Frekans Değerleri (n=2I)

\begin{tabular}{|l|c|}
\hline Fiziksel ve ortopedik güçlük & f \\
\hline Fiziksel öğrenme çevresini bireyin özelliğine göre düzenlerim & 13 \\
\hline Öğrencinin sınıfına uyumunu sağlamak & 6 \\
\hline Yetersizliğin engele dönüşmemesi için onunla sıklıkla görüşme yapmak & 5 \\
\hline $\begin{array}{l}\text { Bu öğrencilere akranlarının yanında kendilerini kötü hissetmemeleri ve kendini kabul için rehberlik } \\
\text { etmek }\end{array}$ & 5 \\
\hline $\begin{array}{l}\text { Yapabileceği etkinliklerde ona görev/rol vererek yetersizliğin engele dönüşmemesini sağlamada çaba } \\
\text { göstermek }\end{array}$ & 4 \\
\hline Sınıf öğretmeni ile işbirliğinde öğrencinin engelini sınıfta izah ederim & 4 \\
\hline Sınıfta arkadaşlarının onunla dalga geçmelerini engellerim & 3 \\
\hline Arkadaşlarına öğrencinin yaşadığı zorlukları anlatırım & 1 \\
\hline $\begin{array}{l}\text { İhtiyaç varsa gerekli mercilere başvurarak taşıma ve evde eğitim hizmetlerinden yararlanmasını } \\
\text { sağlarım }\end{array}$ & 1 \\
\hline \multicolumn{1}{|c|}{ Toplam } & 42 \\
\hline
\end{tabular}

Tablo 5 incelendiğinde katılımcılar fiziksel ve ortopedik güçlük yaşayan bireylerle karşılaşabileceklerini ifade etmektedirler. Öğrenciler böyle bir durumda baskın biçimde güçlük yaşayan öğrencilerinöğrenmeortamınıbireyinözellikleridoğrultusunda düzenlenmesi eğiliminde olacaklarını ifade etmektedirler. Yine fiziksel ve ortopedik yetersizlik yaşayan öğrencilerin sınıfına uyumunu sağlamak, öğrenciyle sıkça bireysel görüşme yaparak onu desteklemek ve akranları arasında sosyal kabul için çaba gösterecekleri ifade edilmektedir. Psikolojik danışma ve rehberlik öğrencileri sınıf öğretmeni ile işbirliği içinde olacaklarını belirtmelerinin yanı sıra öğrencinin etiketlenerek alay konusu olmaması için de sorumluluk alacaklarını vurgulamaktadırlar. 
Tablo 6:

Öğrencilerin Kaynaştırma Öğrencisine Illişkin Görüşlerinin Frekans Değerleri (n=2l)

\begin{tabular}{|l|c|}
\hline Kaynaştırma öğrencisi & f \\
\hline Akranlarını bilinçlendirmek & 5 \\
\hline Öğrenciye BEP planı hazırlamak & 4 \\
\hline Sını öğretmeni ile koordineli çalışmak & 4 \\
\hline Gelişimine yönelik kayıtlar tutmak & 3 \\
\hline Öğrenciyi tanılaması için hemen RAM a göndermemek & 2 \\
\hline Öğrenciyle yakından, bireysel olarak ilgilenmek & 2 \\
\hline Öğretmenle derse girip destek olmak & 1 \\
\hline Ailesiyle öğrenciyi tanımak amaçlı iletişime geçmek & 1 \\
\hline Öğrencilere arkadaşlarını anlamaları için empati içeren etkinlikler yapmak & 9 \\
\hline & Toplam \\
\hline
\end{tabular}

Tablo 6’ya göz attığımızda n=21 öğrenci, kaynaştırma öğrencisi ile karşılaşabileceğini ifade etmektedir. Bu durumda öğrencilerin eğiliminin kaynaştırma öğrencisinin aynı sınıfta öğrenim gördükleri arkadaşlarını bilinçlendirmek, öğrenci için BEP planının hazırlanması ve sınıf öğretmeni ile koordineli çalışarak öğrenci hakkında gelişim durumuna ilişkin kayıtları tutma şeklinde davranış sergileyeceklerini belirtmektedirler.

\section{Tablo 7}

Öğrencilerin Zihinsel Yetersizliğe Ilişkin Görüşlerinin Frekans Değerleri ( $n=14)$

\begin{tabular}{|l|c|}
\hline Zihinsel yetersizlik & f \\
\hline Tanıma ve zihinsel yetersizliğin derecesini belirlemek için test uygulama & 12 \\
\hline RAM’a yönlendirmek (tanılama ve değerlendirme) & 11 \\
\hline Uygun eğitim ortamlarında eğitim görmesi için yönlendirmek & 5 \\
\hline BEP planı hazırlamak & 4 \\
\hline Aileye test sonuçlarına göre öğrencinin uygun eğitim ortamlarına yönlendirilmesi için bilgilendirmek & 3 \\
\hline Akranları normal zeka düzeyi arkadaşlarıyla birlikte vakit geçirecek etkinlikler düzenlerim & 1 \\
\hline \multicolumn{1}{|c|}{ Toplam } & 36 \\
\hline
\end{tabular}

Araştırmaya katılan öğrencilerden $n=14$ tanesi zihinsel yetersizlik yaşayan öğrencilerle karşılaşabileceğini düşünmektedirler. Tablo 7 incelendiğinde ise bu durumda öğrencilerin zihinsel yetersizlik yaşadığını düşündükleri bireyleri tanımak ve doğru karar vermek için tanıma ve zihinsel yetersizliğin derecesini belirlemek için test uygulama eğilimlerinde olacaklarını ve akabinde uygun eğitim ortamlarından yararlandırılması için öğrenciyi RAM’a yönlendireceklerini ifade etmektedirler. Benzer biçimde yine aile ile iletişime geçerek öğrencinin uygun ortamlara yönlendirileceği bilgilendirmeler yapılacağı da vurgulanan diğer bir görüştür. 
Marmara Üniversitesi Atatürk Eğitim Fakültesi Eğitim Bilimleri Dergisi / Journal of Educational Sciences

Yıl: Haziran 2016 • Cilt-Sayı 44・ISSN: |300-8889・ ss. 53-7|

\section{Tablo 8}

Öğrencilerin Öğrenme Güçlüğüne Illişkin Görüşlerinin Frekans Değerleri (n=12)

\begin{tabular}{|c|c|}
\hline Öğrenme güçlïğ̈̈ & f \\
\hline Öğrencinin seviyesine uygun çalışma planı ve öğrenme(öğretme) etkinlikleri hazırlamak & 5 \\
\hline Okula kaynak oda ve özel alt sınıf kurulması için çaba göstermek & 4 \\
\hline Özel ilgi göstererek benlik algısının düşmemesini desteklemek & 3 \\
\hline Öğrenciye uygun etkinlikle planlayarak yetersizliğini öğrenciye hissettirmemek & 3 \\
\hline Öğrencinin gelişim düzeyini yakından takip etmek & 2 \\
\hline Aile ve öğretmenle iletişim kurmak & 2 \\
\hline Öğrenciyi tahtaya yakın sıralarda oturtarak öğretmenle iletişimini canlı tutmak & 1 \\
\hline Toplam & 20 \\
\hline
\end{tabular}

Araştırmada bazı öğrenciler ( $n=12)$ öğrenme güçlüğü yaşayan bireylerle karşılaşabileceklerini düşünmektedirler. Bu durumla karşılaşıldığında ise öğrencilerin tepkileri tablo 8 incelendiğinde; öğrencinin seviyesine uygun çalışma planı ve öğrenme-öğretme etkinlikleri hazırlamak, okul bünyesinde ihtiyaç durumunda kaynak oda ve özel alt sınıf kurulması için çaba göstermek, öğrencinin benlik algısının düşmemesi için onu desteklemek ve öğrencinin seviyesine uygun etkinlikler planlayarak öğrencinin kendisini yetersiz hissetmemesi yönünde çaba göstermek şeklinde sıralanmaktadır.

\section{Tablo 9}

Öğrencilerin Bireysel Eylem Planı Hazılamaya Ilişkin Görüşlerinin Frekans Değerleri $(n=12)$

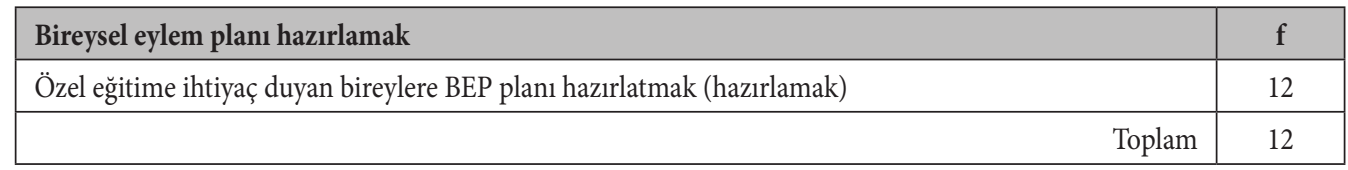

Araştırmaya katılan öğrenciler $(n=12)$ farklı yetersizlik alanlarında olmakla birlikte özel eğitime ihtiyaç duyan öğrenciler için, doğrudan bir psikolojik danışman ve rehberlik çalışanı olarak engel ve yetersizlik yaşayan öğrencilerin öğrenim ortamlarının düzenlenmesi için BEP hazırlamak sorumluluğunda olacaklarını ifade etmektedir. 
Tablo 10

Öğrencilerin Otizme Ilişkin Görüşlerinin Frekans Değerleri $(n=10)$

\begin{tabular}{|c|c|}
\hline Otizm & f \\
\hline Çocuğun iş eğitimi veya OÇEM okullarına yönlendiririm & 4 \\
\hline Normal akranlarına bu öğrenciler konusunda farkındalık sağlamak & 4 \\
\hline Aileleri otizmli bireylerin farklı iletişim kurduklarına dair bilinçlendiririm & 3 \\
\hline Özel alt sinıflara yönlendirmek & 2 \\
\hline Günlük pratik beceriler kazandırırım & 2 \\
\hline Aileye öğrenciye ilgi ve sabır göstermesinde destek olmak & 1 \\
\hline Otizmin hastalık değil farklı iletişim tarzı olduğunu benimserim. & 1 \\
\hline & 17 \\
\hline
\end{tabular}

Tablo 10'da görüldügü üzere psikolojik danışma ve rehberlik öğrencileri özel eğitim dersi kapsamında otizm tanısı konulmuş bireylerle karşılaştıklarında bu bireylerin iş eğitim okulu veya otistik çocuklar eğitim merkezlerine (OÇEM) yönlendirme yapacaklarını ifade etmektedirler. Katılımcıların bazıları akranlarıyla aynı eğitim ortamında olmak üzere, özel alt sınıflarda öğrenim gören otizm tanısı konulmuş öğrencileri normal akranlarına tanıtacaklarını ifade etmektedirler. Yine katılımcılar tanılaması yapılan bu öğrenciler için ailelerine ilgi ve sabır gösterilmesi konusunda destek olunacağı ve günlük işlerdeki pratik becerilerin kazandırılması konusunda eğitimsel olarak öğrencilerin desteklenmesi gerektiğine dikkat çekmektedirler.

\section{Tablo I I}

Öğrencilerin Konuşma Ve Dil Bozukluklarına Ilişkin Görüşlerinin Frekans Değerleri (n=9)

\begin{tabular}{|c|c|}
\hline Konuşma ve dil bozuklukları & f \\
\hline Öğrenciyle sinıfta dalga geçilmesini önlemek & 4 \\
\hline $\begin{array}{l}\text { Öğrencilerin güçlük yaşayan arkadaşına özür ve yetersizliğinden dolayı uygun (kekeme vb) hitap } \\
\text { etmelerini sağlamak }\end{array}$ & 3 \\
\hline Öğrencilerin arkadaşına hitaplarında güçlük yaşayan birey biçiminde uygun dil kullanımını sağlamak & 2 \\
\hline Öğrencinin sınıfta olmadığı bir zamanda sınıf arkadaşlarına bilgi vermek & 2 \\
\hline Dille ilgili konuşma pratikleri yaptırmak & 2 \\
\hline Öğretmenleri bilgilendirmek & 1 \\
\hline Çevreye uygun davranışlarımla öğrenciye uygun model olmak & 1 \\
\hline Olası nedenleri belirlemeye çalışmak & 1 \\
\hline Öğrenciyi sabırla dinlemek & 1 \\
\hline Toplam & 17 \\
\hline
\end{tabular}

Tablo 11 incelendiğinde $n=9$ öğrenci konuşma ve dil bozuklukları yaşayan öğrencilerle karşılaşabileceklerini düşünmektedirler. Bu konuda ise öğrenciler öncelikle akranları tarafından sınıfta dalga geçilmesini önlemeyi amaçlayacaklarını belirtmektedirler. Yine benzer konuda öğrenciler konuşma ve dil bozuklukları yaşayan bireylere sınıfta akranlarının etiketleyici bir 
dil kullanmamalarına önem vereceklerini ifade etmektedirler. Ayrıca Tablo 11 incelendiğinde konuşma güçlüğü yaşayan öğrencinin durumu hakkında öğrencinin sınıfta olmadığı bir zamanda sınıf arkadaşlarına bilgi vermek, dille ilgili konuşma pratikleri yaptırmak ve çevreye uygun davranışlarla model olacaklarını belirtmektedirler.

Tablo 12

Öğrencilerin Hiperaktivite Bozukluğuna Iliş̧kin Görüşlerinin Frekans Değerleri (n=9)

\begin{tabular}{|c|c|}
\hline Hiperaktivite & $\mathrm{f}$ \\
\hline Sinıf öğretmenlerine rehberlik etmek & 3 \\
\hline Öğrencinin uygun bir spor faaliyetine yönlendirilmesini sağlarım & 3 \\
\hline Öğrencilere konsantrasyon egzersizleri yaparak dersi dinlemelerini desteklemek & 1 \\
\hline Öğrencilere bireysel psikolojik danışma yapmak & 1 \\
\hline Öğrenci arkadaşlarına empati yapacak uygulamalarda bulunmak & 1 \\
\hline Enerjisini harcayacak sorumluluklar vermek & 1 \\
\hline Toplam & 11 \\
\hline
\end{tabular}

Araştırma kapsamında görüş belirten öğrenciler $(n=9)$ öğrencilerde hiperaktivite ile karşılaşabileceklerini belirtmektedirler. Bu durumda olan öğrencilerin öğretmenlerine rehberlik yapmak ve öğrencinin enerjisini atacağı bir spor faaliyetine yönlendirilmesi konusunda çaba göstereceklerini ifade etmektedirler.

Tablo 13

Öğrencilerin Sara Nöbetine Ilişkin Görüşlerinin Frekans Değerleri (n=9)

\begin{tabular}{|l|c|}
\hline Sara nöbeti & f \\
\hline $\begin{array}{l}\text { Derste öğrendiğim nöbet esnasında müdahale (dilinin boğazına kaçmasını engelleme, yan yatırma, } \\
\text { köpük çkışı, baş alıını desteklemek vb.) yollarını uygulama }\end{array}$ & 9 \\
\hline Önce kendim sakin olurum & 4 \\
\hline Arkadaşlarına saranın bulaşıcı olmadığı konusunda bilinçlendirme & 4 \\
\hline Sınıfı sakinleştiririm & 1 \\
\hline Sara nöbeti geçiren öğrencinin bu durumda utanmaması için kendisine danışmanlık yaparım & 1 \\
\hline \multicolumn{1}{|c|}{ Toplam } & 19 \\
\hline
\end{tabular}

Tablo 13 incelendiğinde psikolojik danışma ve rehberlik öğrencileri $(n=9)$ sara gibi konvülsiyon (epilepsi) bozukluklar ile karşı karşıya kalabileceklerini ifade etmektedirler. $\mathrm{Bu}$ durumda öğrenciler derste öğrendiklerini ifade ettikleri müdahale yöntemlerini kullanacaklarını belirtmektedir. Yine bazı öğrenciler sara nöbetini yaşandığı esnada nöbet geçiren öğrencinin sınıftaki arkadaşlarına model olmak için öncelikle öğretmen olarak kendilerinin sakin kalmaları gerektiğini düşünmektedirler. Nöbet sonrası öğrencilere saranın bulaşıcı bir rahatsızlık olmadı̆̆ konusunda öğrencileri bilinçlendirmek ve nöbet geçiren öğrencinin de yaşanan durumdan utanmaması için öğrenciye destek sağlanması gerektiğini düşünmektedirler. 
Tablo 14

Öğrencilerin Tarama Faaliyetine Illişkin Görüşlerinin Frekans Değerleri (n=7)

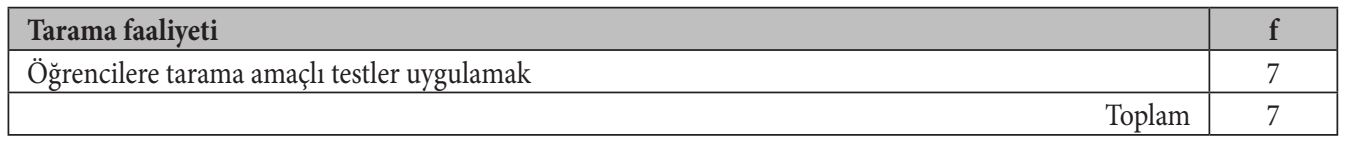

Tablo 14 incelendiğinde araştırmada veri sağlayan 7 öğrenci ise özel eğitime ihtiyaç duyabilecek öğrencilerin arama bulma faaliyeti olarak tarama faaliyetleri yapmak durumu ile karşı karşıya kalabileceklerini düşünmektedirler.

Tablo 15

Öğrencilerin Özel Eğitime İhtiyaç Duyan Öğrenci Aileleri Konusundaki Görüşlerinin Frekans Değerleri $(n=5)$

\begin{tabular}{|c|c|}
\hline Özel eğitime ihtiyaç duan öğrenci aileleri & f \\
\hline Aileye kabul ve uyuma geçiş aşamasında yardımcı olmak & 5 \\
\hline Aileyle iletişimde kendini ifade etmesine imkân vererek etkin dinleyici olmak & 1 \\
\hline Aileyle öğrenci hakkında sürekli iletişim halinde olmak & 1 \\
\hline Toplam & 7 \\
\hline
\end{tabular}

Tablo 15 incelendiğinde öğrencileri bir diğer uğraş alanlarının özel eğitime ihtiyaç duyan öğrencilerin aileleri ile etkileşimde bulunmak olduğu düşünülmektedir. Bu durumda öğrenciler ailenin yaşadığı bu zor ve destek gerektiren durumda ailenin çocuğunu kabul ve uyum aşamasına geçişinde yardımcı olmak, aileyle iletişimde etkin bir dinleyici olmak ve aile ile sürekli iletişimde bulunulması gerektiği düşünülmektedir.

Tablo 16

Öğrencilerin Işitme Güçlüğüne Illişkin Görüşlerinin Frekans Değerleri (n=5)

\begin{tabular}{|c|c|}
\hline İşitme güçlüğü & f \\
\hline Öğrencinin kullandığı cihazı tanıtmak ve hassasiyeti akranlarına anlatmak & 2 \\
\hline Cihaz kullanmadan dolayı öğrencinin okula gelmek istememesi durumunda onu ikna etmek & 1 \\
\hline Öğrencinin empati oluşturacak etkinlikler yaparak sosyal kabulünü sağlamak & 1 \\
\hline Tarama yapmak & 1 \\
\hline Öğrenciyi öğretmeni görecek cephede ve ön sıralara oturtmak & 1 \\
\hline Toplam & 6 \\
\hline
\end{tabular}

Tablo 16 incelendiğinde öğrencilerin işitme güçlüğü yaşayan bireylerle karşılaşılabileceği düşünülmektedir. Böylesi bir durumda da işitme güçlüğü yaşayan bireyin kullandığı cihazının sınıfa tanıtılması ve hassasiyeti öğrencilere vurgulanması gerektiği düşünülmektedir. Öğrenciler 
ayrıca sınıfta empati içeren uygulamalarla öğrencinin akranlarında sosyal kabulü sağlanacağı belirtilmektedir.

\section{Tablo 17}

Öğrencilerin Görme Güçlüğüne Illişkin Görüşlerinin Frekans Değerleri (n=3)

\begin{tabular}{|c|c|c|}
\hline Görme güçlüğü & & $\mathrm{f}$ \\
\hline Uygun uzaklıkta oturtmak & & 3 \\
\hline Görme konusunda okulda tarama yapmak & & 2 \\
\hline & Toplam & 5 \\
\hline
\end{tabular}

Tablo 17 incelendiğinde öğrenciler görme güçlüğü yaşayan ve özel eğitime ihtiyaç duyabilecek bir bireyle karşılaşabilecekleri düşünülmektedir. Bu durumda ise sınıfta oturma düzeni olarak ortam ayarlaması yapacaklarını, uygun bir uzaklıkta öğrencinin oturtulmasını sağlayacaklarını belirtmektedirler. Ayrıca görme yetersizliği yaşayan bireyler için çalıştıkları kurumda tarama testleri yapacakları belirtilmiştir.

\section{Tablo 18}

Öğrencilerin Süreğen Hastalıklara Illişkin Görüşlerinin Frekans Değerleri (n=2)

\begin{tabular}{|lr|c|}
\hline Süreğen hastalıklar & f \\
\hline Öğrencileri hastalık hakkında bilgilendirmek & 2 \\
\hline & Toplam & 2 \\
\hline
\end{tabular}

Araştırmada sadece $n=2$ öğrenci süreğen hastalıklara maruz kalan öğrenci ile karşılaşabileceklerini düşünmektedir. Böylesi durumda ise süreğen hastalık yaşayan öğrencinin akranlarına bu durum ve hastalık hakkında bilgilendirme yapacaklarını ifade etmişlerdir.

Tablo 19

Öğrencilerin Özel Eğitime Sahip Bir Anne Olmaya Illişkin Görüşlerinin Frekans Değerleri $(n=1)$

\begin{tabular}{|lr|c|}
\hline Özel eğitime sahip bir anne & f \\
\hline Uyum evresine geçip çocuğum için çaba gösteririm & 1 \\
\hline & Toplam & 1 \\
\hline
\end{tabular}

Tablo 19 incelendiğinde psikolojik danışma ve rehberlik öğrencilerinden sadece bir tanesi özel eğitimin hayatında nerede karşısına geçeceği şeklindeki araştırma sorusuna özel eğitime ihtiyaç duyan bir çocuk annesi olarak karşılaşabileceğini ifade etmiştir. Böyle bir durumda karşılaştığında ise uyum evresine geçerek çocuğu için çaba göstereceğini de belirtmektedir. 


\section{Sonuç ve tartışma}

Bu araştırmada 2013-2014 eğitim öğretim yılında güz döneminde Amasya Üniversitesi’nde 2. sınıfta öğrenim gören psikolojik danışma ve rehberlik öğrencilerinin öğretim programlarında yer alan özel eğitim dersini tamamladıktan sonra bu dersin kendilerinde hangi konularda kazanımlar sağladığının belirlenmesi amaçlanmıştır. Bu amaç doğrultusunda şu sonuçlara ulaşılmıştır.

Öğrenciler mesleki yaşamlarında özel eğitim alanında karşılaşabilecekleri durumları ve bu durumlar karşısında ne yapabileceklerine ilişkin görüşleri incelendiğinde öğrencilerin en fazla karşılaşabilecekleri durumlar sırasıyla; duygu ve davranış bozukluğu, üstün zekâlı öğrenciler, fiziksel ve ortopedik yetersizlik ve kaynaştırma öğrencisi olabileceğini belirtmişlerdir. Araştırmada dikkat çeken bir diğer bulgu; özel eğitime ihtiyaç duyabilecek bir çocuk sahibi anne olarak bu gerçekliği yaşayabilirim düşüncesinde olabileceğini düşünen sadece bir öğrencinin olmasıdır.

Öğrencilerin dersin kazanımları doğrultusunda farklı engel alanlarını ayırt ettikleri ve bu alanlara ilişkin farklı ve dersin kazanımlarına uygun yaklaşımlar sergiledikleri (örn: otizmli bireye yönelik olarak "Aileleri otizmli bireylerin farklı iletişim kurduklarına dair bilinçlendiririm" ya da sara nöbetine ilişkin "derste öğrendiğim nöbet esnasında müdahale (dilinin boğazına kaçmasını engelleme, yan yatırma, köpük çıkışı, baş altını desteklemek vb.) yollarını uygulama”) saptanmıştır.

Öğrencilerin tarama ve yönlendirme faaliyetlerini sıklıkla vurgulamaları "eğitsel değerlendirme ve tanılama erken yaşta yapılır” ilkesini benimsediklerini göstermektedir. Bunun yanı sıra tüm engel alanlarında ortak olarak sergilenmesi gereken kazanımlara ulaştıkları görülmektedir. Psikolojik danışmanlık ve rehberlik öğrencilerinin diğer eğitim fakültesi öğrencilerine göre uygulama alanında farklı görev ve sorumlulukları vardır (MEB, 2012). Özel eğitime ihtiyaç duyan öğrencilerin taranmasından, ilgili kurumlara yönlendirilmesinden, kaynaştırma eğitimine tabi olmalarından, bireysel eğitim programı hazırlama sürecinde işbirliği yapmalarından, ailelere danışmanlık yapmaya kadar geniş bir yelpazede öğrencilerin kendi alanlarına ilişkin kazanımlara sahip oldukları görülmektedir. Ancak öğrencilerin "BEP” hazırlarım”, "öğrenciyi ön sıraya oturturum”, "Fiziksel öğrenme çevresini bireyin özelliğine göre düzenlerim” biçiminde ifadelerinin eğitim ortamlarında bu görevleri ya da kararları tek başına verebilecekleri izlenimi oluşturduğundan üzerinde düşünülmesi gereken ifadeler olarak görülebilir. Özel gereksinimli öğrencilerin başarıya ulaşmalarında ailenin, okul yönetiminin, öğretmenlerin ve uzmanların işbirliği içinde hareket etmeleri önemlidir. Ayrıca yine "BEP" hazırlama sürecinde psikolojik danışman ve rehber öğretmenin esas sorumlu değil sürecin bir parçası olduğu "BEP” hazırlama sürecinde aileye, öğrenciye ve öğretmene danışmanlık yapması gerektiği bu ders sürecinde öğrencilere vurgulanmalıdır.

Eğitim fakültesi öğrencilerinin özel eğitim derslerini almaları tüm eğitim kademelerinde özel eğitime ihtiyacı olan öğrenciler olduğundan oldukça önemlidir. Çünkü özel eğitim dersi ya da eğitimi alan öğrencilerin kaynaştırmaya yönelik olumlu tutum geliştirmekle ilişkili olduğunu (Gözün ve Yıkmış, 2004; Orel, Zerey ve Töret, 2004), özel eğitim dersinin yanında özel eğitimle ilgili projelere katılımın özel eğitime ilişkin olumlu tutumları geliştirdiği (Melekoğlu, 2013) 
görülmektedir. Bu bakımdan psikolojik danışma ve rehberlik öğrencilerinin özel eğitime ilişkin olumlu tutum geliştirmelerinin önemli olduğu düşünülebilir. Ayrıca özel eğitim hizmetlerinin başarıya ulaşmasında öğretmen, yöneticiler, ailelerin işbirliği yapması (Gözün ve Yıkmış, 2004) vurgulanmaktadır.

Sonuç olarak ve rehberlik öğrencilerinin özel eğitim dersi kapsamında karşılaşabilecekleri sorun alanları ve bu sorun alanları ile karşılaştıklarında ne yapabileceklerinin yanı sıra gelecek araştırmalarda sınıf öğretmenlerinin olası destek istemeleri durumunda (örn: davranış sorunlarını gidermek, belli derslerdeki güçlükleri yenmek vb) öğrencilerin sergileyecekleri tutum ve davranışların belirlenmesi önemli olabilir. Özel eğitim hizmetleri yönetmeliği (2012) ve rehberlik ve psikolojik danışma hizmetleri yönetmeliğinde (2001) rehber öğretmenini görev ve sorumluluklarına ilişkin çeşitli ifadeler yer almaktadır. Bu yönetmeliklerde rehber öğretmenin, özel eğitime muhtaç öğrencinin belirlenmesi, tanılanması, rehberlik ve araştırma merkezine yönlendirme sürecinde aileye rehberlik edilmesi yapılmasının yanında BEP (Bireysel eğitim planı) hazırlama kurullarında BEP hazırlama sürecinde işbirliği yapması vurgulanmaktadır. Bu doğrultuda psikolojik danışma ve rehberlik öğrencilerine yönelik verilen özel eğitim derslerinde yönetmelikte ifade bulan ilgili maddelerin kazanımının önemle üzerinde durulması sağlanabilir. Böylece psikolojik danışma ve rehberlik bölümünden mezun olan danışman adaylarının çalışma yaşamlarında özel eğitimle ilgili karşılaşabileceği sorunların üstesinden gelmelerinin ve özel eğitim öğrencileri ve ailelerine rehberlik etmesinin kolaylaşacağı düşünülebilir.

Özel eğitim ders programının muhtevası ve hitap ettiği alan düşünüldüğünde psikolojik danışman ve rehber öğretmenlerinin bu alanda kendilerini yetiştirmeleri oldukça önem taşımaktadır. Bu alandaki derslerin çeşitliliğinin arttırılması veya seçmeli derslerin konulması beklenen yeterliklerin gelişmesine katkı sağlayabilir. Öğretmen yetiştiren kurumlarda özel eğitim dersinde öğrencilerden, yetersizlik yaşayan ya da engelli bireylerin topluma katılımını sağlamaya yönelik bir proje geliştirmelerinin istenmesi dersin etkisini arttıracağı düşünülmektedir 


\section{Kaynaklar}

Aksoy, V. ve Diken, İ.H. (2009). Rehber öğretmen özel eğitim öz yeterlik ölçeği: Geçerlik ve güvenirlik çalışması, Ankara Üniversitesi Eğitim Bilimleri Fakültesi Özel Eğitim Dergisi, 10(1), 29-37. http:// dergiler.ankara.edu.tr/dergiler/39/1414/15965.pdf adresinden alınmıştır.

Bakırcıoğlu, R. (2005). İlköğretim, ortaöğretim ve yükseköğretimde rehberlik ve psikolojik danışma. Ankara: Anı Yayıncilık

Batu, E.S. (2013). Özel eğitimde personel işbirliği. A. Cavkaytar (Ed.), Özel eğitim (s. 21-35). Ankara: Vize Yayıncilık.

Batu, E.S., Kırcaali-İftar, G. ve Uzuner, Y. (2004). Özel gereksinimli öğrencilerin kaynaştırıldığı bir kız meslek lisesindeki öğretmenlerin kaynaştırmaya ilişkin görüş ve önerileri, Ankara Üniversitesi Ĕ̆itim Bilimleri Fakültesi Özel Eğitim Dergisi, 5 (2), 33-50.

http://dergiler.ankara.edu.tr/dergiler/39/52/488.pdf adresinden alınmıştır.

Gök, G. ve Erbaş, D. (2011). Okulöncesi eğitimi öğretmenlerinin kaynaştırma eğitimine ilişkin görüşleri ve önerileri. International Journal of Early Childhood Special Education, 3(1). 66-87.

http://dergipark.ulakbim.gov.tr/intjecse/article/view/5000016557/5000016363 adresinden alınmıştır.

Gözün, Ö. ve Yıkmış, N. (2004). İlköğretim müfettişlerinin kaynaştırma uygulamasına ilişkin görüş ve önerileri. Ankara Üniversitesi Eğitim Bilimleri Fakültesi Özel Eğitim Dergisi, 5(2), 79-88. http:// dergiler.ankara.edu.tr/dergiler/39/52/496.pdf adresinden alınmıștır.

Gözün, Ö. ve Yıkmış, A. (2004). Öğretmen adaylarının kaynaştırma konusunda bilgilendirilmelerinin kaynaştırmaya yönelik tutumlarının değişimindeki etkililiğ̆i. Ankara Üniversitesi Eğitim Bilimleri Fakültesi Özel Eğitim Dergisi, 5(2), 65-77.

http://dergiler.ankara.edu.tr/dergiler/39/52/496.pdf adresinden alınmıştır.

Kargın, T. (2010). Özel Gereksinimi olan öğrencilerin yerleştirilmesi ve BEP. G. Akçamete (Ed.), Genel eğitim okullarında özel gereksinimi olan öğrenciler ve özel ĕgitim (s.77-112). Ankara: Kök Yayıncılık.

Kuzgun, Y. (2000). Rehberlik ve psikolojik danışma. Ankara: ÖSYM Yayınları.

M.E.B. (2012). Özel Ĕ̆itim Hizmetleri Yönetmeliği,

http://orgm.meb.gov.tr/meb_iys_dosyalar/2012_10/10111226_ozel_egitim_hizmetleri_yonetmeligi_son. pdf adresinden alınmıştır.

M.E.B. (2001). Rehberlik ve Psikolojik Danışma Hizmetleri Yönetmeliği.

http://mevzuat.meb.gov.tr/html/68.html adresinden alınmıştır.

Melekoglu, M.A., Cakiroglu, O. ve Malmgren, K.W. (2009). Special education in Turkey. International Journal of Inclusive Education, 13(3), 287-298,

doi: 10.1080/13603110701747769

Melekoğlu, M.A. (2013). Özel gereksinimli öğrencilerle yürütülen etkileşim projesinin genel eğitim öğretmenlerinin kaynaştırma uygulamalarına yönelik olumlu tutum ve farkındalık geliştirmeleri üzerindeki etkilerinin belirlenmesi. Kuram ve Uygulamada Ĕ̈itim Bilimleri, 13 (2), 1053-1077. http://www.edam.com.tr/kuyeb/pdf/tr/1e63c43788d378940733327c561aff69glutr.pdf adresinden alınmıştır.

Merriam, S.B. (2013). Nitel araştırma: Desen ve uygulama için bir rehber. (S. Turan, Çev.). Ankara: Nobel Yayıncilı.

Orel, A., Zerey, Z. ve Töret, G. (2004). Sınıf öğretmeni adaylarının kaynaştırmaya yönelik tutumlarının incelenmesi. Ankara Üniversitesi Eğitim Bilimleri Fakültesi Özel Eğitim Dergisi, 5(1), 23-33, http:// dergiler.ankara.edu.tr/dergiler/39/51/477.pdf adresinden alınmıştır. 
Marmara Üniversitesi Atatürk Eğitim Fakültesi Eğitim Bilimleri Dergisi / Journal of Educational Sciences YIl: Haziran 2016 • Cilt-Sayı $44 \cdot$ ISSN: I300-8889 • ss. 53-7I

Saraç, T. ve Çolak, A. (2012). Kaynaştırma uygulamaları sürecinde ilköğretim sınıf öğretmenlerinin karşılaştıkları sorunlara ilişkin görüş ve önerileri. Mersin Üniversitesi Eğitim Fakültesi Dergisi, 8(1), http://dergipark.ulakbim.gov.tr/mersinefd/article/view/1002000236/1002000172 adresinden alınmıştır.

Şenel, H.G. (1998). Special education in Turkey. European journal of special needs education, 13(3), 254-261, http://www.tandfonline.com/doi/pdf/10.1080/0885625980130304 adresinden alınmıştır.

Yeşilyaprak, B. (2013). Eğitimde rehberlik hizmetleri. Ankara: Nobel Yayın Dağıtım.

Yıldırım, A. ve Şimşek, H. (2005). Sosyal bilimlerde nitel araştırma yöntemleri. Ankara: Seçkin Yayıncilık. 
